\title{
Utilización de espectrometría de masas para la identificación precoz de hemocultivos positivos. Validación de un algoritmo local
}

\author{
Beatrice Hervé, Valerie Corvalán, Sara Hormazábal, Alberto Salas, Catalina Cabezas, \\ Nora Badilla, Rodrigo Munizaga, Fabiola Quintana y Sebastián de la Fuente
}

\section{Use of mass spectrometry for rapid diagnosis of positive blood cultures. Validation of a local algorythm}

Mass spectrometry (MS) is used in identification of positive blood culture, a contribution in the clinical management of septic patients. The protocol is labor intensive and disrupts the normal workflow in a clinical laboratory. We intended to make rapid diagnosis by using MS directly from shortly incubated blood agar plates (4 to 6 hours) comparing with results of the conventional method (MC). We worked in parallel 145 positive blood cultures, with correct identification by short method in $79 \%$ of cases. We observed better yield with non carbon bottles and with gramnegative rods. With this information we designed a rapid identification algorithm using MS, which allows advancing diagnosis in 12-16 hours, without increasing to the costs or work load, since extraction protocol is not used.

Key words: Mass spectrometry, blood culture, laboratory diagnosis.

Palabras clave: Espectrometría de masas, hemocultivos, diagnóstico de laboratorio.

\section{Introducción}

$\mathrm{E}$ 1 análisis proteómico de microorganismos por espectrometría de masas (EM) es una metodología confiable, económica y rápida, que muestra resultados promisorios al compararlo con métodos convencionales (MC). Se ha publicado reportes que indican que la EM puede ser utilizada con buenos resultados en la identificación a partir de muestra directa, con protocolos publicados para urocultivo y hemocultivo, destacando el aporte que esto significa en el manejo clínico del paciente séptico $^{1-5}$. Sin embargo, la aplicación de los protocolos publicados para hemocultivo resulta laboriosa e interrumpe el flujo normal de trabajo de un laboratorio, ya que en el momento en que un hemocultivo da alarma de positivo, debe haber un profesional disponible para realizar la secuencia completa de concentración-centrifugación, lavado y re suspensión de pellet que indica el procedimiento, lo que no siempre existe en la práctica diaria.

En nuestro centro aplicamos el protocolo Sepsytiper (Bruker) el año 2012 en 39 muestras de hemocultivo positivo (Bact/alert, BioMerieux), logrando $74 \%$ de diagnóstico directo, que se veía fuertemente reducido si el frasco de hemocultivo tenía carbón activado (datos presentados en el XVI Congreso Chileno de Tecnología Médica). Dado que este resultado no resultó satisfactorio, se mantuvo el método convencional de identificación (incubación por $18 \mathrm{~h}$ en placas y luego identificación por EM a partir de colonias). Durante el primer semestre de 2014, estudiamos en paralelo los frascos de hemocultivo positivo, por método convencional, comparando con el rendimiento de realizar una identificación a ciegas por EM a partir de placas incubadas durante 4 a $6 \mathrm{~h}$ (sin colonias visibles), con el objetivo de conocer la correlación entre ambos métodos, según el tipo de frasco y el tipo de microorganismo. En base a la información obtenida, establecimos un flujograma de trabajo que permite adelantar el diagnóstico de los hemocultivos positivos en 12 a $16 \mathrm{~h}$.

\section{Material y Método}

Se incluyó en el estudio las muestras de hemocultivo positivo detectados por equipo Bact/alert, entre el 1 de enero y 30 de junio de 2014. Los frascos detectados como positivos por este equipo fueron procesados según un protocolo rutinario de hemocultivo (observación de tinción de Gram con informe inmediato al tratante, inoculación en placa de agar sangre, McConkey y PVX y realización de identificación por EM a las 18 h, cuando se obtienen colonias visibles y antibiograma directo en placa de agar Mueller-Hinton, según la orientación inicial de la tinción de Gram). En paralelo, se realizó la identificación a ciegas desde el inóculo en la placa de agar sangre, por Vitek MS
Clínica Las Condes

Santiago, Chile.

Laboratorio Clínico.

Conflictos de interés: no hay Fuente de financiamiento: no hay

Recibido: 6 de marzo de 2015 Aceptado: 9 de julio de 2015

Correspondencia a: Beatrice Hervé Espejo bherve@clc.cl 
(BioMerieux). Se registró para cada hemocultivo positivo, la hora de procesamiento a ciegas ( 4 a 6 post inoculación), realizando un arrastre con un asa del área inoculada en la placa, cargando dos pocillos de la placa de identificación de Vitek MS. La identificación obtenida precozmente fue

\begin{tabular}{|cccc|}
\hline \multicolumn{5}{|c|}{ Tabla 1. Rendimiento de Identificación precoz, según tipo de frasco } \\
\hline $\begin{array}{c}\text { Tipo de } \\
\text { frasco }\end{array}$ & $\begin{array}{c}\mathbf{n} \text { tot } \\
\text { positivos }\end{array}$ & $\begin{array}{c}\mathbf{n} \text { identificación precoz concordante } \\
\text { con identificación } \mathbf{1 8 ~ h}\end{array}$ & $\begin{array}{c}\text { \% identificación } \\
\text { precoz concordante }\end{array}$ \\
FA & 53 & 35 & 66 \\
PF & 21 & 14 & 67 \\
SA & 54 & 50 & 93 \\
\hline SN & 17 & 16 & 94 \\
\hline Total & 145 & 115 & 79,3 \\
\hline FA y PF: frascos con carbón activado. SA, SN: frascos sin carbón activado.
\end{tabular}

Tabla 2. Rendimiento identificación precoz según tipo de microorganismo

Tipo de $\quad n$ total $n$ concordantes por identificación \% identificación microorganismo identificados precoz vs identificación $18 \mathrm{~h}$ precoz concordante

$\begin{array}{crrc}\text { BNEG } & 72 & 62 & 86 \\ \text { CPOS } & 62 & 49 & 79 \\ \text { LEVAD } & 7 & 4 & 57 \\ \text { BPOS } & 2 & 0 & 0 \\ \text { Mixto } & 2 & 0 & 0 \\ \text { Total } & 145 & 115 & 79,3\end{array}$

BNEG: bacilo gram negativo; CP OS: cocacea gr am positivo; LEVAD:levadura;BPOS:bacilo gram positivo. Mixto: desarrollo de mas de un $m$ icroorganismo

Tabla 3. Correlación de Identificación de Cocaceas Gram positivo por método tradicional vs precoz

$\begin{array}{cc}\text { Identificación } & \mathrm{n} \text { identificados por método } \\ \text { tradicional } & \mathrm{n} \text { identificados por método } \\ \text { de identificación precoz }\end{array}$

E. fecalis

64

S. agalactias 3

$\begin{array}{lll}\text { S. epidermidis } & 23 & 21\end{array}$

S. haemolyticus $\quad 4 \quad 3$

S mitis $\quad 2 \quad 1$

S. salivarius $\quad 1 \quad 1$

S. aureus 44

S. capitis

S. hominis

1

S. lugdunensis

S. pneumoniae

S. pyogenes

S. salivarius + epidermidis

Total (\%)

9

1

1

1

1

$62(100 \%)$

$9(79 \%)$ corroborada posteriormente (a las $18 \mathrm{~h}$ ) por Vitek MS o Vitek 2 Compact (BioMerieux). Los resultados de ambos procesos fueron comparados en relación al resultado de identificación. Se tomó en cuenta el tipo de frasco y el tipo de microorganismo detectado. Se consideró identificación correcta un nivel de identificación por Vitek MS > 95\% en género y especie, concordante con la identificación convencional. Valores menores se consideraron correctos en género si correspondían efectivamente al género identificado por MC.

\section{Resultados}

Durante el período que duró el estudio hubo 165 frascos de hemocultivo positivos en nuestro laboratorio, de los cuales se trabajó en paralelo 145. En relación al tipo de frasco, $51 \%$ de los frascos trabajados tenían carbón activado. Se logró la identificación correcta por método acortado en $115(79,3 \%)$, siendo 66\% para frascos con carbón y $93 \%$ para frascos sin carbón (Tabla 1). La identificación de bacilos gramnegativo fue de $86 \%$, cocáceas grampositivo $79 \%$ y levaduras $57 \%$ (Tabla 2). La distribución de especies identificadas se muestra en las Tablas 3 a 5 . La mayor parte de las identificaciones fueron con 99,9\% de confiabilidad, excepto en Staphylococcus coagulasa ne-

\section{Tabla 4. Correlación de Identificación de Bacilos Gram} negativo por método tradicional vs precoz

\begin{tabular}{|lcc|}
\hline Identificación & Tradicional & Precoz \\
\hline A. xilosoxidans & 4 & 4 \\
A. baumannii & 2 & 2 \\
E. cloacae & 1 & 1 \\
E. coli & 45 & 39 \\
K. pneumoniae & 11 & 9 \\
P. mirabilis & 2 & 2 \\
P. aeruginosa & 5 & 4 \\
Salmonella & 1 & 1 \\
S. maltophilia & 2 & 2 \\
Total (\%) & $72(100 \%)$ & 62 (86\%) \\
\hline
\end{tabular}

Tabla 5. Correlación de identificación de levaduras por método tradicional vs precoz

\begin{tabular}{|lcc|}
\hline Identificación & Tradicional & Precoz \\
\hline C. lusitaniae & 1 & 1 \\
C. parapsilosis +C. lusitaniae & 1 & 0 \\
C. tropicalis & 5 & 3 \\
Total (\%) & $7(100 \%)$ & $4(57 \%)$ \\
\hline
\end{tabular}


gativa, en que la identificación tendió a ser con valores de certeza alrededor de 96\%, y en el caso de Achromobacter spp, Enterobacter spp y Streptococcus grupo viridans, la identificación por EM fue correcta a nivel de género, pero no permitió diferenciar entre especies. En los casos en que hubo discordancia (n: 2), la identificación precoz por EM dio un porcentaje de confianza bajo (menor de 73 y $76 \%$ ) y no pudo corroborarse posteriormente. Se trató en ambos casos, de bacilos grampositivo, posibles contaminantes. En base a estos resultados, se definió un algoritmo de trabajo que se presenta en la Figura 1, el que incluye algunas consideraciones especiales a tener en cuenta al momento de informar.

\section{Discusión}

Este trabajo muestra que es posible utilizar la metodología de EM, sin tener que recurrir a protocolos que entorpecen el flujo normal de trabajo en el laboratorio, con buenos resultados. Creemos que es un aporte para el manejo clínico, como lo han demostrado diversos estudios de impacto en el uso apropiado y oportuno de antimicrobianos en pacientes con sepsis ${ }^{4,5}$, ya que nos permite adelantar la identificación 12 a $16 \mathrm{~h}$ respecto de la identificación tradicional, con una identificación correcta en 4 de 5 casos (el caso restante queda sin identificación). Cabe destacar que los mejores resultados se logran con bacilos gramnegativo, y cuando se trata de un frasco de hemocultivo que no contiene carbón activado, lo que concuerda con datos publicados ${ }^{6-8}$. Aunque no era un objetivo planteado inicialmente, se observó que había mejores resultados si la identificación se realizaba a las 5 ó 6 h, en comparación con $4 \mathrm{~h}$. La mediana de horas en que se hizo la identificación acortada fue 5. Sin embargo, en el peor de los casos, se puede intentar a las $4 \mathrm{~h}$, y si no se obtiene una identificación confiable, se puede repetir unas horas después, o esperar a tener colonias visibles, según los MC. Con la aplicación de este algoritmo, se logra adelantar la identificación sin aumentar los costos ni la carga de trabajo del laboratorio, aunque es necesario considerar que para obtener la máxima eficiencia de este sistema de trabajo, se requiere un laboratorio de microbiología que funcione las 24 h del día, todos los días.

En el grupo de muestras estudiadas, hubo dos casos en que la identificación por método acortado no fue igual al método tradicional $(1,7 \%)$. Ambos casos se trató de microorganismos no habituales, en que Vitek MS los identificó con baja discriminación. En microorganismos habituales, no hay discordancias. Es destacable que cultivos mixtos no son identificados y en levaduras hubo un menor rendimiento, que puede obedecer a una baja presencia de Candida albicans en el grupo de muestras de este estudio, y una muestra mixta con dos levaduras

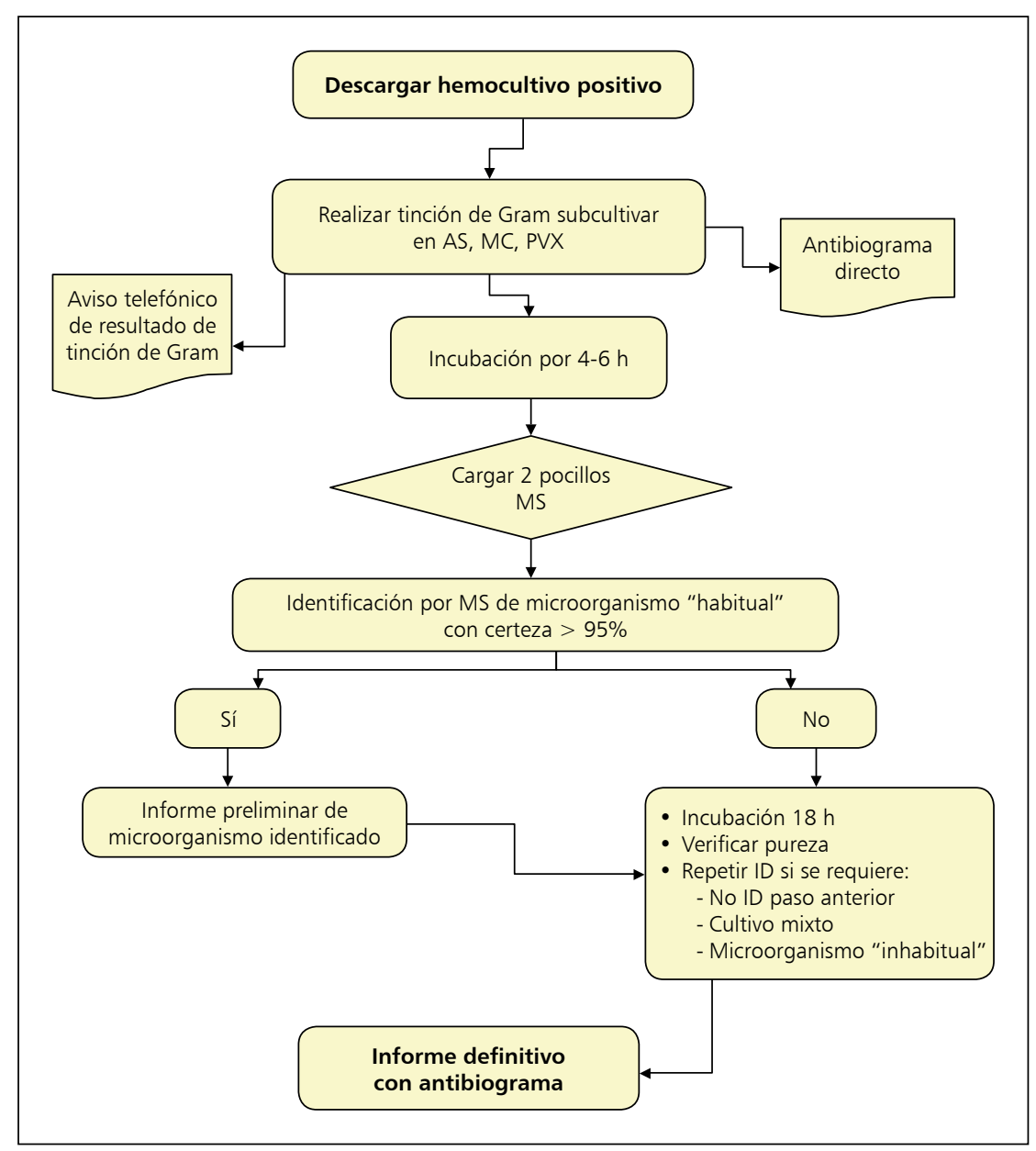

Figura 1. Algoritmo propuesto para el diagnóstico microbiológico empleando espectrometría de masa precoz en hemocultivos.

diferentes, ambos factores que reducen el rendimiento 9 .

Al analizar el rendimiento de esta metodología según tipo de microorganismo (grampositivo o gramnegativo), se observa que bacilos gramnegativo presentaron mejor rendimiento que cocáceas grampositivo (86 y $79 \%$, respectivamente). En 9 de 10 casos en que no se logró identificar precozmente un bacilo gramnegativo, y en 10 de 13 casos en que no se logró identificar precozmente una cocácea grampositivo, se trataba de frascos con carbón activado. Esto fue más notorio en Escherichia coli, ya que de 45 cepas, 24 fueron obtenidas en frasco con carbón activado, y seis de éstos no pudieron ser identificados precozmente.

Cabe destacar en cuanto a resultados de antibiograma, que con el estado actual de la tecnología en el laboratorio de microbiología, aún es necesario esperar los tiempos convencionales para contar con resultados de susceptibilidad a antimicrobianos, por lo que una identificación 
del microorganismo en forma precoz, es un elemento que aporta a la decisión terapéutica, en base a las sensibilidades locales conocidas.

Al momento de la redacción de este artículo, sólo hemos encontrado un trabajo que aborda este enfoque metodológico (identificación de hemocultivo positivo mediante EM luego de un corto período de incubación en medio sólido), con resultados comparables a los obtenidos por nosotros ${ }^{10}$.

\section{Resumen}

Espectrometría de masas (EM) es utilizada en identificación de hemocultivo positivo (HMP), constituyendo un aporte en el manejo clínico de paciente séptico. El protocolo de identificación directa es ultra laborioso, interrumpiendo el flujo de trabajo normal del laboratorio. Con el objetivo de hacer identificación rápida, utilizamos EM a partir de placas de agar sangre con incubación breve (4 a 6 h), comparando resultados con el método convencional en HMP. Se trabajó 145 frascos de HMP, identificando correctamente por método acortado $79 \%$ de los microorganismos. El rendimiento fue mejor en frascos sin carbón activado y en la identificación de bacilos gramnegativo. Con esta información, diseñamos algoritmo para la identificación precoz de hemocultivo positivo mediante EM, procesando a ciegas a las 4 a 6 h de incubación, lo que permite adelantar el diagnóstico en 12-16 h respecto del método tradicional, sin aumentar los costos ni la carga de trabajo, ya que no se utiliza protocolo de extracción.

\section{Referencias bibliográficas}

1.- Del Peloso P, da Costa Leite C, Torres Filho H, Nunes J. Direct identification of pathogens in blood cultures by MALDI-TOF. J Infect Control 2013; 2 (2): 128-9.

2.- Lagacé-Wiens P, Adam H, Karlowsky J, Nichol K, Pang P, Guenther J, et al. Identification of blood culture isolates directly from positive blood cultures by use of matrixassisted laser desorption ionization-time of flight mass spectrometry and a commercial extraction system: analysis of performance, cost, and turnaround time. J Clin Microbiol 2012; 50 (10): 3324-8.

3.- Machen A, Drake T, Wang Y. Same day identification and full panel antimicrobial susceptibility testing of bacteria from positive blood culture bottles made possible by a combined lysis-filtration method with MALDITOF vitek mass spectrometry and the Vitek2 System. PLOS ONE 2014; (2): e87870.

4.- Huang A, Newton D, Kunapuli A, Gandh T,
Washer L, Isip J, et al. Impact of rapid organism identification via matrix-assisted laser desorption/ionization time-of-flight combined with antimicrobial stewardship team intervention in adult patients with bacteremia and candidemia. Clin Infect Dis 2013; 57 (9): 1237-45.

5.- Vlek A, Bonten M, Boel C. Direct matrixassisted laser desorption ionization time of flight mass spectrometry improves appropriateness of antibiotic treatment of bacteremia. PLOS ONE 2012; 7 (3): e32589.

6.- Klein S, Zimmermann S, Kohler C, Mischnik A, Alle W, Bode K. Integration of matrix-assisted laser desorption/ionization time-of-flight mass spectrometry in blood culture diagnostics: a fast and effective approach. J Med Microbiol 2012; 61: 323-31.

7.- Konnerth S, Rademacher G, Suerbaum S, Ziesing S, Sedlacek L, Vonberg R. Identification of pathogens from blood culture bottles in spiked and clinical samples using matrixassisted laser desorption ionization time-of- flight mass-spectrometry analysis. BMC Res Notes 2014; 7: 405.

8.- Schmidt V, Jarosch A, März P, Sander C, Vacata V, Kalka-Moll W. Rapid identification of bacteria in positive blood culture by matrixassisted laser desorption ionization time-offlight mass spectrometry. Eur J Clin Microbiol Infect Dis 2011; DOI 10.1007/s10096-0111312-0.

9.- Parisi F, Tronci M, Sanguinetti M, Tumbarello G, Canu G, Trecarichi E, et al. Direct MALDI-TOF mass spectrometry assay of blood culture broths for rapid identification of Candida species causing bloodstream infections: an observational study in two large microbiology laboratories. J Clin Microbiol 2012; 50 (1): 176-9.

10.- Idelevich E, Schule I, Grunastel B, Wullenweber J, Peters G, Becker K. Rapid identification of microorganisms from positive blood cultures by MALDI-TOF mass spectrometry subsequent to very short-term incubation on solid medium. Clin Microbiol Infect 2014; 20: 1001-6. 